\title{
Mononuclear phagocytes in rheumatoid arthritis: Fc-receptor expression by peripheral blood monocytes
}

\author{
S. D. CARTER, ${ }^{1} \mathrm{~J} . \mathrm{T} . \mathrm{BOURNE},{ }^{2} \mathrm{C} . \mathrm{J} . \mathrm{ELSON},{ }^{1} \mathrm{C} . \mathrm{W} \cdot \mathrm{HUTTON},{ }^{2} \mathrm{R} . \mathrm{CZUDEK},{ }^{3}$ \\ A N D P. A. DIEPPE ${ }^{2}$ \\ From the ${ }^{1}$ Immunobiology Group, Department of Pathology, University of Bristol, the ${ }^{2}$ Department of \\ Medicine, Bristol Royal Infirmary, and the ${ }^{3}$ South Western Regional Blood Transfusion Centre, Bristol
}

SUMMARY Fc receptor expression by enriched monocytes from rheumatoid arthritis (RA) patients and age and sex matched controls (healthy subjects) was compared by measuring the uptake of IgG on monocytes in a competitive radioassay. The association constant $(\mathrm{Ka})$ between $\operatorname{IgG}$ and the monocytes and the number of Fc binding sites per cell was calculated from Scatchard plots of $4^{\circ} \mathrm{C}$ binding data. RA monocytes had increased expression of Fc receptors as compared with those of controls. This increase was particularly pronounced in those RA patients affected by extraarticular disease. There were significant correlations between the numbers of Fc receptors on monocytes and both $\mathrm{C1q}$ binding and anticomplementary activity but none between monocyte $\mathrm{Fc}$ receptor numbers and serum rheumatoid factors ( $\mathrm{IgG}$ and $\operatorname{IgM})$. It is considered that monocyte handling of circulating immune complexes is unimpaired in RA and that monocytes make an adaptive response to increased levels of immune complexes.

Rheumatoid arthritis (RA) patients frequently have high levels of circulating antigen-antibody complexes. Complexes circulate because their rate of formation equals or exceeds their rate of removal, and it has been suggested that the functioning of the cells involved in complex clearance, the cells of the mononuclear phagocyte system (MPS), is impaired in RA patients. Although the clearance rate of heatdamaged erythrocytes is slower in RA patients than in normal individuals, ${ }^{1}$ it is not known if this defect in clearance extends to the removal of soluble antigenantibody complexes. On the contrary, far from saturating the MPS it has been argued that soluble complexes may stimulate phagocytes. ${ }^{2}$

One manifestation of phagocyte activation is an increase in $\mathrm{Fc}$ receptor expression. ${ }^{3}$ This led us to ask if expression of $\mathrm{Fc}$ receptors by monocytes was altered in patients with RA. To achieve this it was necessary to purify and test monocytes without stimulation. Hence surface adherence was avoided, and the monocytes were obtained by density gradient

Accepted for publication 16 September 1983.

Correspondence to Dr S. D. Carter, Immunobiology Group, Department of Pathology, University of Bristol, The Medical School, University Walk, Bristol BS8 1TD. separation. ${ }^{4}$ Purified human IgG was used in the monomeric form as the ligand, as this allows the determination of both the association constant $(\mathrm{Ka})$ and the number of $\mathrm{Fc}$ receptors expressed in a homologous system.

\section{Patients and methods}

Seventeen patients ( 16 female, 1 male) with classical or definite RA (American Rheumatism Association criteria) were studied. Their mean age was 60.5 years (range 50-65) and mean duration of disease 8 years (range 2 months -26 years). All the patients had active synovitis, as assessed by the Ritchie index, but 2 had morning stiffness of less than 30 minutes. Ten patients had active synovitis alone and 7 had significantly active extra-articular manifestations including nodules (in 6) and /or vasculitis (in 6). Vasculitis was diagnosed clinically by the presence of nail fold infarcts. There was no difference in Ritchie score between patients with or without extra-articular manifestations of disease. All patients were off steroid or second-line therapy at the time of investigation and for at least 2 months before. Most were receiving nonsteroidal anti-inflammatory therapy 
only. Sixteen age and sex matched healthy subjects served as controls.

MONOCYTE FCR-IgG BINDING ASSAY

$A$ radiometric assay was employed as previously described. ${ }^{4}$ Briefly, monocytes were obtained from human peripheral blood $(50 \mathrm{ml})$ by discontinuous gradient separation followed by continuous gradients of Percoll (Pharmacia). Total and differential cell counts (with Giemsa stain and detection of endogenous peroxidase with $\alpha$-naphthylacetate) were performed to determine cell numbers. The cell preparation was $40-80 \%$ monocytes, the contaminating cells being large or small lymphocytes.

The ligand used was human IgG which was prepared by salt precipitation followed by ion exchange on diethylaminoethyl cellulose, and any oligomers were removed on Sephacryl S-300 to produce monomeric IgG. Aliquots were labelled with ${ }^{125}$ I by the iodogen method. ${ }^{5}$

The binding assay was performed in ovalbumincoated LP3 tubes. Radiolabelled IgG (20 ng) was mixed with cold $\mathrm{IgG}(0-1000 \mathrm{ng})$ and monocytes to a final volume of $200 \mu \mathrm{l}$ and the tubes incubated at $4^{\circ} \mathrm{C}$ for 4 hours. The cells were washed 3 times with TC199 (Wellcome) at $4^{\circ} \mathrm{C}$ and the cell pellets counted for attached ${ }^{125} \mathrm{I}$ in an LKB 1270 gamma counter. In each experiment 5 different concentrations of $\operatorname{IgG}$ were used. The $\operatorname{IgG}$ uptake by monocytes from an RA patient and an age and sex matched control were determined in the same experiment. Scatchard plot analysis of the ratio of bound: free IgG (r/c) plotted against the concentration of bound IgG (r) facilitated the determination of the association constant (Ka) from the slope of the plot, and the total number of binding sites was derived from the intercept on the abscissa.

SERA IMMUNE COMPLEX ASSAYS

Solid-phase C1q binding was determined by the method of Verrier-Jones and Cummings. ${ }^{6}$

The complement consuming assay was adapted from the method of Harkiss and Brown. ${ }^{7}$ It involved the polyethylene glycol 6000 (PEG) precipitation of complexes from sera and the assay of their ability to consume complement and inhibit the lysis of sensitised erythrocytes. The complement consumption of serum PEG precipitates was compared with that of standard dilutions of heat aggregated (30 minutes at $63^{\circ} \mathrm{C}$ ) human $\mathrm{IgG}$ and their activity expressed as microgram equivalents of aggregated human IgG per millilitre of serum.

RHEUMATOID FACTOR ASSAYS

Classical rheumatoid factor (IgM) was measured by the sensitised sheep cell agglutination test (SCAT) and results expressed as $\mathrm{IU} \mathrm{mF}^{-1}$. IgG rheumatoid factor was measured by a solid phase radiometric assay employing rabbit $\operatorname{IgG}$ as the antigen. ${ }^{8}$

The levels of rheumatoid factor containing complexes which can convert complement were measured by the method described more fully elsewhere. ${ }^{9}$ Essentially, microtitre plates coated with bovine conglutinin and blocked with BSA were incubated with patients' sera $(10 \mu \mathrm{l})$ and normal human sera $(10 \mu \mathrm{l})$ at $37^{\circ} \mathrm{C}$ for $30 \mathrm{~min}$. Addition of soybean trypsin inhibitor prevented $\mathrm{C} 3$ bi inactivation. After 16 hours' incubation at $4^{\circ} \mathrm{C}$ the plates were washed, ${ }^{125}$ I-heat-aggregated IgG (Hagg) added, and then incubated for 16 hours at $20^{\circ} \mathrm{C}$. After further washes the wells were cut out of the plates and their radioactivity counted. All samples were tested in duplicate and results expressed as $\mu \mathrm{g}$ Hagg bound per millilitre of serum.

Statistical analyses. Comparisons of data from RA patients and healthy subjects were made by Student's $t$ test. Correlations were determined by linear regression analysis.

\section{Results}

EXPRESSION OF FCR BY BLOOD MONOCYTES

Monocyte binding of $\operatorname{IgG}$ was shown to occur in a linear manner by Scatchard plot analysis in RA patients and controls. The binding association constant (Ka) was not significantly different between the RA patients and controls (Fig. 1a). However, there was an increase in Fc receptor numbers in RA patients $(p<0 \cdot 001)$. Moreover, there were significantly $(p<0.02)$ more Fc receptors expressed on monocytes from patients with extra-articular disease than on monocytes from patients with synovitis alone (Fig. 1b).

\section{SEROLOGICAL MEASUREMENTS}

Elevated levels of $\mathrm{C} 1 \mathrm{q}$ binding material were detected in RA patients compared with controls (Fig. 2a). The differences were significant in comparisons between RA patients with synovitis alone and controls $(p<0.001)$ and comparisons between RA patients with extra-articular disease and controls $(p<0 \cdot 001)$. Furthermore, RA patients with extraarticular disease had higher C1q binding $(p<0 \cdot 001)$ than the synovitis group $(p<0 \cdot 01)$. Increased levels of anticomplementary activity were detected in the sera of patients with extra-articular disease $(p<0.001)$ but not in patients with synovitis (Fig. 2b).

Raised levels of IgG rheumatoid factor were found in patients with synovitis $(p<0.001)$ and extraarticular disease $(p<0.002)$ compared with healthy subjects (Fig. 3a). Classical (IgM) rheumatoid factors were raised in RA patients with synovitis alone 


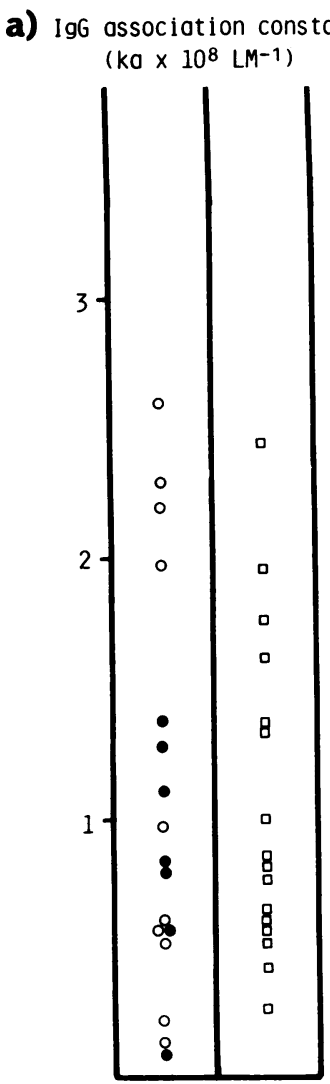

RA Control b) $\mathrm{FCR} / \mathrm{cell}\left(10^{-3}\right)$

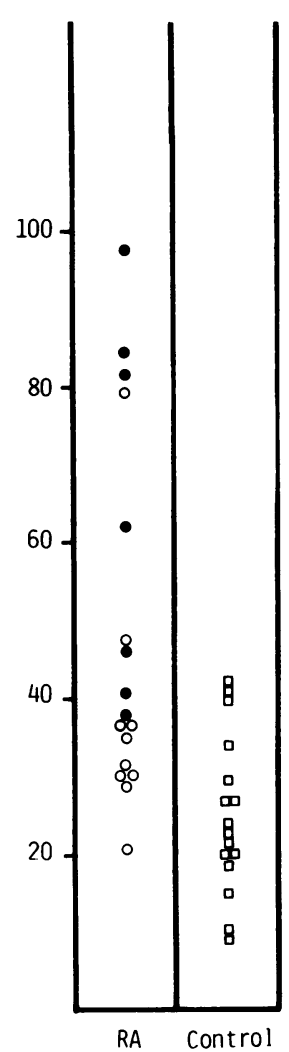

a) Cla binding (\%)

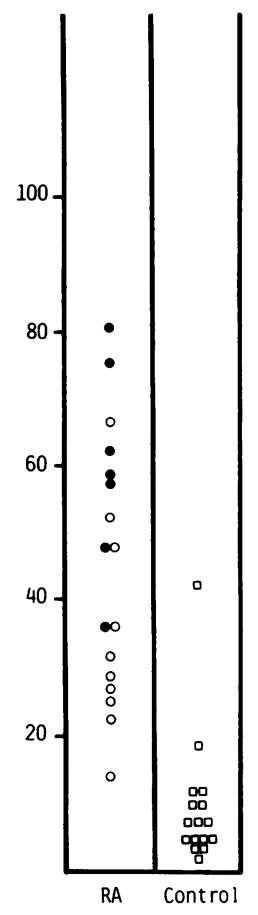

b)
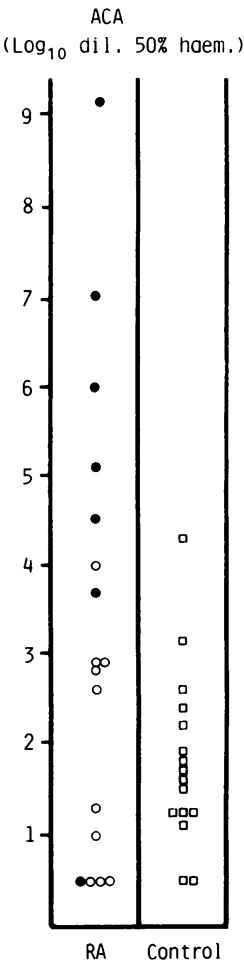

Fig. 2 Serum immune complex assays in healthy subjects and RA patients. (a) Clq binding activity. (b) Anticomplementary activity. $=$ Extra-articular disease. $\mathrm{O}=$ Synovitis.

Fig. 1 Binding of IgG to purified blood monocytes from $R A$ patients and healthy subjects. (a) Association constant $(\mathrm{Ka})$. (b) $F$ c receptors/cell. 0 = Extra-articular disease. $O=$ Synovitis.

$(p<0.001)$ and even more so in the patients with extra-articular disease $(p<0.001)$ (Fig. 3b).

$\mathrm{RF}$-containing complexes fixing $\mathrm{C} 3$ were raised in synovitis patients $(p<0.01)$ and even more so in patients with extra-articular disease $(p<0.001)$ (Fig. 3c).

\section{CORRELATION OF FCR EXPRESSION WITH SEROLOGICAL MEASUREMENTS}

Linear regression analysis of the data for the RA patients showed that there was some correlation (Fig. $4 a, b)$ between numbers of FcR/cell and C1q binding activity $(p<0.02)$ and numbers of FcR/cell and anticomplementary activity $(p<0 \cdot 02)$. No correlation was found with FcR numbers and the levels of rheumatoid factors (IgG or IgM) or with the level of RF fixing C3. Neither the age of patients nor a clinical 
a) IgG RF
$(\mu g / \mathrm{ml}$ sera $)$

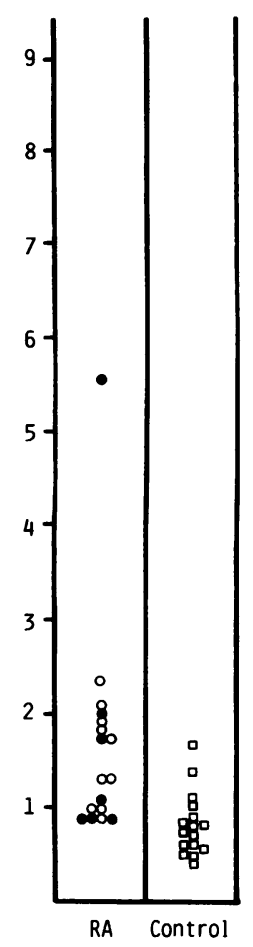

a)

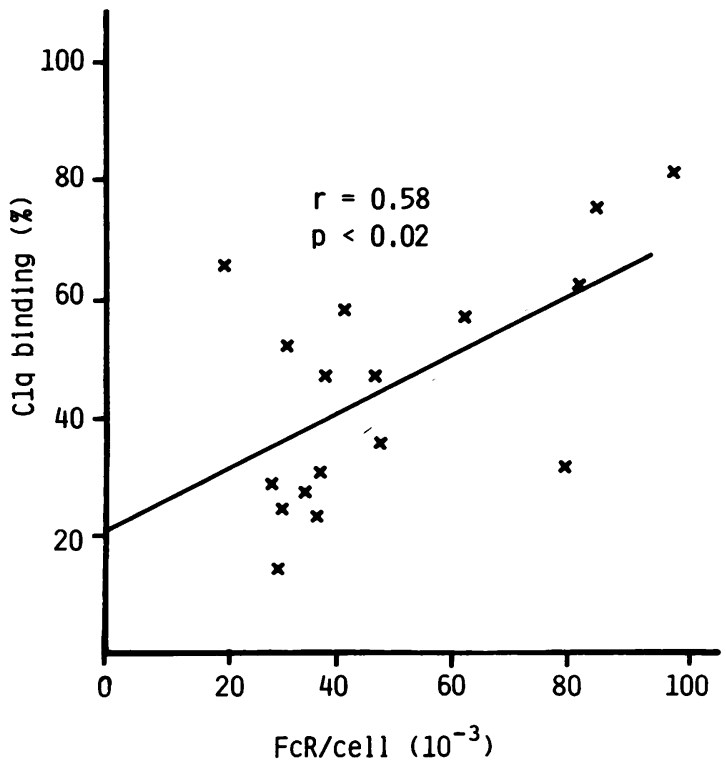

C) $\quad \mathrm{RF}-\mathrm{C3}$

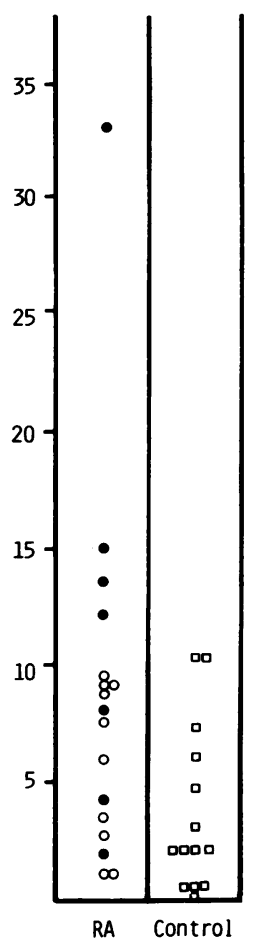

Fig. 3 Serum rheumatoid factors in healthy subjects and $R A$ patients. (a) IgG rheumatoid factors. (b) $\mathrm{IgM}$ rheumatoid factors. (c) $C-3$ fixing rheumatoid factors. $=$ Extra-articular disease. $\mathrm{O}=$ Synovitis.

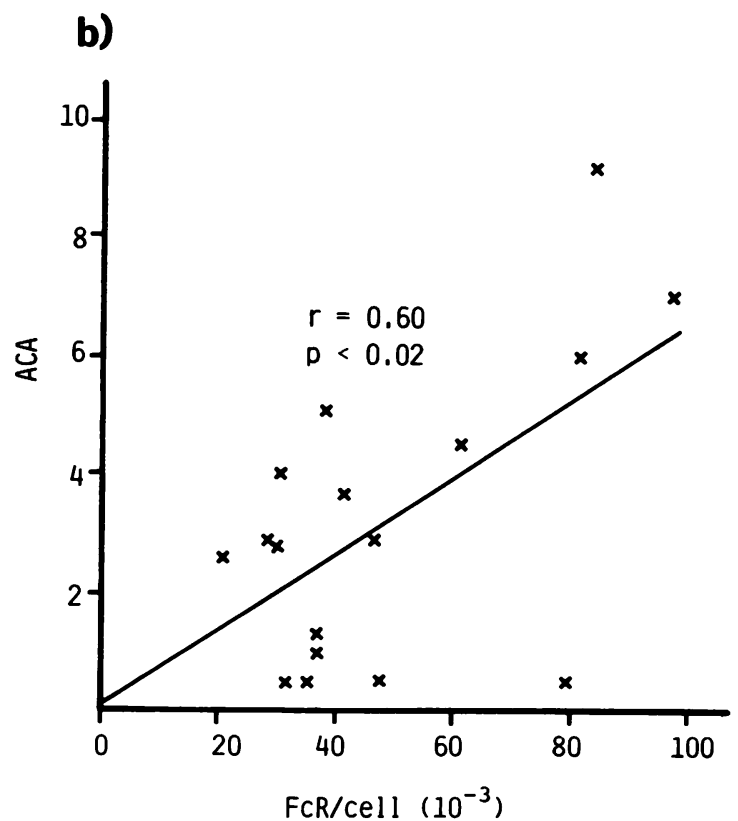

Fig. 4 Correlation between monocyte FcR numbers and (a) serum C1q binding activity. (b) Serum anticomplementary activity in RA patients. 
FcR. Also, in the latter study the monocytes were purified by adherence to a solid phase, a process which itself can alter cell metabolism. ${ }^{12}$

Activated monocytes exhibit an increase in Fc receptor numbers. Thus the increase in $\mathrm{FcR}$ receptor expression by peripheral blood monocytes in RA may be because these cells are activated. This would agree with reports showing enhanced complement synthesis ${ }^{13}$ and increased antibody dependent cell mediated cytotoxicity ${ }^{14}$ by monocytes from RA patients. The monocytes could be activated by a serum factor such as the products of sensitised lymphocytes or immune complexes as both are known to activate monocytes in vitro. ${ }^{15-17}$

Compared with controls the RA patients, particularly those patients with extra-articular disease, had elevated levels of circulating antigen-antibody complexes as judged by serum C1q binding and anticomplementary activity. The elevated complex levels were associated with increased numbers of $F c R$ receptors on monocytes. The possibility arises that monocyte FcR expression may be stimulated by circulating complexes. This suggestion gains credence from recent results showing increased monocyte Fc receptor expression in SLE. ${ }^{18}$ Here, too, receptor expression correlated with complex levels. As the attachment phase is the rate determining step in phagocytosis $^{19}$ the level of Fc receptor expression will influence the ability of monocytes to phagocytose IgG-containing complexes. In this way persisting circulating complexes may promote more effective removal of circulating IgG-containing complexes. Perhaps increased Fc receptor expression on circulating monocytes is an adaptation to defective Fc receptor function at other sites. Reduced clearance rates of IgG sensitised autologous erythrocytes have been found in patients with SLE ${ }^{20}$ and of heat damaged erythrocytes in RA patients. ${ }^{1}$ In both cases this correlated with increased C1q binding activity in patients' sera. The monocytes from such patients are those which should exhibit the highest $\mathrm{Fc}$ receptor expression.

Although both IgG RF and IgM RF were elevated in the RA patients, particularly those with extraarticular disease, there was no correlation with monocyte Fc receptor numbers. On the one hand this renders it unlikely that RFs alter monocyte metabolism in a way that alters FcR expression. On the other hand it argues against RFs contributing to IgG uptake by attaching to cytophilic IgG on monocytes and then binding further IgG. Evidence against these possibilities also comes from the observation that incubation of normal monocytes in RA sera with a high level of IgM RF failed to increase the monocyte uptake of aggregated IgG. ${ }^{11}$ In this work the cells were washed before purification, as this is the most effective method of preventing cytophilic IgG remaining attached to monocytes. ${ }^{21}$

Monocytes enriched by density flotation are contaminated with lymphocytes. As some lymphocytes express FcR, these could take up the IgG in the binding assay. However, there is no correlation between monocyte purity and numbers of FcR detected, and the uptake of IgG by lymphocytes is less than $10 \%$ of the amount bound by equivalent numbers of monocytes. ${ }^{4}$ Finally, the lymphocytes harvested in the monocyte enriched portion of the Percoll density gradient are the low-density lymphocytes, and these are the weakest IgG binders among lymphocytes. ${ }^{22}$ It is currently debated whether the mononuclear phagocyte system is defective in RA. RA patients do exhibit reduced splenic function. ${ }^{1}$ Despite this, the current results suggest that blood monocytes are actually stimulated in RA.

This work was supported by the Arthritis and Rheumatism Council, Medical Research Council, and the Nuffield Foundation.

\section{References}

1 Williams B D, Lockwood C M, Russel B A, Cotton C. Defective reticuloendothelial system function in rheumatoid arthritis. Lancet 1979; i: 1311-4.

2 Dorrington K J. Properties of the Fc receptor on macrophages and monocytes. Immunol Commun 1976; 5: 263-80.

3 Yodoi J, Masuda T, Majama M, Ichikawa Y. Interaction of lymphocyte and macrophage cell lines (MI cells). 1. Functional maturation and appearance of Fc receptors in M1 cells. Cell Immunol 1978; 39: 5-17.

4 Carter S D, Leslie R G Q, Reeves W G. Human monocyte binding of homologous monomer and complexed IgG. Immunology 1982; 46: 793-800.

5 Fraker P J, Speck J C Jr. Protein and cell membrane iodinations with a sparingly soluble chloroamide $1,3,4,6$ tetrachloro-3a,6a diphenyl glycoluril. Biochem Biophys Res Commun 1978; 80: 849-57.

6 Verrier-Jones J, Cummings R H. Tests for circulating immune complexes. In: Thompson $\mathbf{R}$ A, ed. Techniques in clinical immunology. Oxford: Blackwell, 1977: 136-57.

7 Harkiss G D, Brown D L. Detection of immune complexes by a new assay, the polyethylene glycol precipitation-complement consumption test. Clin Exp Immunol 1979; 36: 117-29.

8 Jones V E, Cowley P J, Allen C, Elson C J. The isolation of immune complexes containing IgM rheumatoid factor and recovery of $\mathrm{IgG}$ rheumatoid factor from the complexes. $J$ Immunol Methods 1981; 37: 1-4.

9 Elson C J, Carter S D, Cottrell B J, et al. Complement activation property of complexes containing rheumatoid factor in synovial fluids and sera from patients with rheumatoid arthritis. Submitted for publication.

10 Möller-Rasmussen J, Brandslund I, Rasmussen G G, Svehag $S$ E. Increased number of IgG Fc receptors on monocyteenriched peripheral blood leucocytes from patients with rheumatoid arthritis. Scand J Immunol 1982; 16: 279-86.

11 Katayama S, Chia D, Nasu H, Knutson D W. Increased Fc receptor activity in monocytes from patients with rheumatoid arthritis: a study of monocyte binding and catabolism of soluble aggregates of IgG in vitro. J Immunol 1981; 127: 643-7.

12 Bodel PT, Nichols B A, Bainton D F. Appearance of peroxidase activity within the rough endoplasmic reticulum of blood monocytes after surface adherence. J Exp Med 1977; 145: 264-74. 
13 De Ceulaer C, Papazoglou S, Whaley K. Increased biosynthesis of complement components by cultured monocytes, synovial fluid macrophages, synovial membrane cells from patients with rheumatoid arthritis. Immunology 1980; 41: 37-43.

14 Kay N E, Douglas S D. Monocyte metabolic activation in patients with rheumatoid arthritis. Proc Soc Exp Biol Med 1979; 161: 303-6.

15 Guyre P M, Crabtree G R, Bodwell J E, Munck A. MLCconditioned media stimulate an increase in Fc receptors on human macrophages. J Immunol 1981; 126: 666-8.

16 Nathan C F, Kamovsky M L, David J R. Alterations in macrophage functions by mediators from lymphocytes. J Exp Med 1970; 133: 1356-76.

17 Pestel J, Joseph M, Dessaint J P, Capron A. Macrophage triggering by aggregated immunoglobulins. 1 . Delayed effect of IgG aggregates or immune complexes. I Immunol 1981; 126: 1887-91.
18 Kavai M, Lukacs K, Sonkoly I, Paloczc K, Szegedi G Y. Circulating immune complexes and monocyte Fc function in autoimmune diseases. Ann Rheum Dis 1979; 38: 79-83.

19 Leslie R G Q, Alexander M D. Cytophilic antibodies. Curr Top Microbiol Immunol 1979; 88: 25-104.

20 Frank M M, Hamburger M I, Lawley T J, Kimberly R P, Plotz $P$ H. Defective reticuloendothelial system Fc receptor function in systemic lupus erythematosus. $N$ Engl $J$ Med 1979; 300: 518-23.

21 Alexander E L, Titus J A, Segal D M. Quantitation of Fc receptors and surface immunoglobulin is affected by cell isolation procedures using plasmagel and Ficoll-hypaque.J Immunol Methods 1978; 22: 263-72.

22 Carter S D, Bacon P A, Hall N D. Characterisation of activated lymphocytes in the peripheral blood of patients with rheumatoid arthritis. Ann Rheum Dis 1981; 40: 293-8. 